\title{
Ensinamentos e contos: Maria Amália Vaz de Carvalho e sua estratégia para a educação da mulher
}

\author{
Teachings and stories: Maria Amália Vaz de Carvalho \\ and her strategy for woman's education
}

Enseñanzas y cuentos: Maria Amália Vaz de Carvalho y su estrategia para la educación de la mujer

Maria Celi Chaves Vasconcelos (iD ${ }^{a}$

\section{Resumo}

O presente estudo tem como objetivo analisar as obras Mulheres e Crianças: notas sobre educação e Contos e Phantasias, acerca da educação feminina, de autoria da poetisa e escritora portuguesa Maria Amália Vaz de Carvalho, ambas publicadas no ano de 1880. Em um plano mais específico, é abordada a concepção da autora sobre um tema inserido nesses dois escritos de Maria Amália, a educação doméstica de meninas realizada por suas próprias mães ou por mestras contratadas para esse fim. No que se refere aos aspectos metodológicos, o artigo apresenta uma pesquisa bibliográfica e analítica, cujas obras foram escolhidas por terem sido elaboradas no mesmo período e por se tratarem de dois gêneros diferenciados: realidade e ficção, igualmente utilizados pela autora como estratégia para convencer suas leitoras de seus ensinamentos. O estudo evidencia que as obras se complementam, à medida que demonstram - seja através dos ensinamentos diretos que Maria Amália oferece para as mulheres, seja por meio dos contos em que constrói narrativas que exemplificam e ilustram os seus conselhos - qual era a educação feminina adequada para o papel a ser exercido pelas mulheres na sociedade do seu tempo, consistindo, unicamente, no de boas esposas, boas mães e boas donas de casa.

Palavras-chave: Educação feminina. Mãe e mestra. Maria Amália Vaz de Carvalho.

\footnotetext{
a Universidade do Estado do Rio de Janeiro (UERJ), Rio de Janeiro, RJ, Brasil. Doutora em Educação, e-mail: maria2.celi@gmail.com
} 


\begin{abstract}
This study aims to analyze the books Mulheres e Crianças: notas sobre educação (Women and Children: notes on education) and Contos e Phantasias (Stories and Fantasies), about female education, authored by the Portuguese poet and writer Maria Amália Vaz de Carvalho, both published in the year 1880. In a specific view, we address the author's conception on a theme inserted in these two writings of Maria Amália, the domestic education of girls carried out by their own mothers or by teachers hired for this purpose. With regard to methodological aspects, the article presents a bibliographic and analytical research, whose books were chosen because they were elaborated in the same period and because they are two different genres: reality and fiction, equally used by the author as a strategy to convince her readers of her teachings. The study shows that the books complement each other, as they demonstrate - either through the direct teachings that Maria Amália offers to women, or through the stories in which she builds narratives that exemplify and illustrate her advice - what was the appropriate female education for the role to be played by women in the society of their time, consisting solely of good wives, good mothers and good housekeepers.
\end{abstract}

Keywords: Female education. Mother and teacher. Maria Amália Vaz de Carvalho.

\title{
Resumen
}

Este estudio tiene como objetivo analizar las obras Mulheres e Crianças: notas sobre educação (Mujeres y Niños: notas sobre la educación) y Contos e Phantasias (Cuentos y Fantasías), sobre la educación femenina, de la poeta y escritora portuguesa Maria Amália Vaz de Carvalho, ambas publicadas en el año 1880. En un plan más específico, se aborda la concepción de la autora sobre un tema insertado en estos dos escritos de María Amália, la educación doméstica de las niñas realizada por sus propias madres o por profesores contratados para tal fin. En cuanto a los aspectos metodológicos, el artículo presenta una investigación bibliográfica y analítica, cuyos trabajos fueron elegidos porque se desarrollaron en el mismo período y porque son de dos géneros diferentes: realidad y ficción, también utilizados por la autora como estrategia para convencer sus lectoras de sus enseñanzas. El estudio muestra que las obras se complementan, ya que demuestran - sea a través de las enseñanzas directas que María Amália ofrece a las mujeres, o mediante los cuentos en los que construye narrativas que ejemplifican e ilustran sus consejos - cuál fue la educación femenina adecuada por el papel que debía desempeñar la mujer en la sociedad de su tiempo, consistiendo, únicamente, en buenas esposas, buenas madres y amas de casa.

Palabras clave: Educación femenina. Madre y maestra. Maria Amália Vaz de Carvalho. 


\section{Introdução}

Maria Amália Vaz de Carvalho é uma escritora portuguesa que nasceu em Lisboa, no dia primeiro de fevereiro do ano de 1847, conforme assegura o seu biógrafo Amaro Carvalho da Silva (1997). Como era costume na época, Maria Amália contou em sua infância com uma ama, chamada Maria de Jesus, que a acompanhou por toda a vida (SILVA, 1997). No entanto, embora seja uma condição corriqueira, tratando-se de amas que prestavam serviços a crianças das camadas mais elevadas da população, chama atenção o fato de Maria de Jesus ser analfabeta, tanto por sua estreita participação na formação daquela que seria uma das mais reconhecidas escritoras de sua época, como por Maria Amália descrever em suas obras a importância do letramento feminino, até mesmo, para as "criadas".

A educação de Maria Amália ocorreu semelhante à das filhas das famílias aristocratas de seu tempo, em que pese a sua pertencer a um "gênero de aristocracia arruinado, teimando em viver acima de suas reais condições de existência" (SILVA, 1997, p. 51). A maior diferença entre ela e as meninas de sua época é que não teve mestras ou preceptoras que a ensinassem na sua própria casa, como era o costume das elites, mas foi a mãe, uma mulher letrada e culta, que lhe ensinou desde as primeiras letras até a sua iniciação literária. Sobre essa escolha restrita à mãe ou à mestra no Portugal de oitocentos, Silva acrescenta: "Como sabemos, a rede escolar primária estava na altura a ser instalada e apenas para o sexo masculino, dando assim a entender que as escolas femininas não existiam na prática” (SILVA, 1997, p. 52).

Sua juventude foi vivida longe da cidade, em uma quinta-palácio em estado decadente naquele momento, localizada em Pintéus, uma povoação próxima a Santo Antão do Tojal, distante, para os padrões das carruagens e carroças, da vida urbana lisboeta. De acordo com Silva (1997, p. 60) e com base nos próprios apontamentos de Maria Amália, essa vida campestre e relativamente reclusa fez com que sonhasse "poeticamente com um mundo idealizado", o que provocou nela, por meio da solidão, grande imaginação, além do gosto intenso pela leitura, especialmente a literatura francesa, da qual pretendeu esgotar tudo o que havia disponível para ler: "Eram mais, eram muitos mais, todos lidos, todos decorados com enternecimento e 
apaixonado enlevo" (SILVA, 1997, p. 61). Tal gosto guardava influência da mãe que nutria uma profunda devoção, "no culto quase fanático" de Napoleão (p. 61).

No entanto, se a educação da mãe foi decisiva naquilo que marcaria a jovem Maria Amália, imprimindo nela os ideais iluministas, por outro lado, essa formação a cargo da mãe seria lembrada com críticas pela escritora, considerando até mesmo que faltou a ela educação, o que pode ser uma referência a mestres ou a uma instituição escolar: "Gostava m.to de puder trabalhar, escrever e fazer alguma cousa que valesse a pena. É tarde! Faltou me quem me educasse, e falta me hoje a força moral que é necessária p. a a gente se educar a si” (SILVA, 1997, p. 63). Ainda que seu biógrafo Amaro Carvalho da Silva atribua seu talento literário também a uma "esmerada educação dada por sua mãe” (1997, p. 63), não parece ser essa exatamente a opinião de Maria Amália, retirada de seus próprios escritos, já na fase adulta.

Ainda assim, não se pode desconsiderar que o ambiente intelectual e de convívio social que se reunia na quinta de Pintéus, em torno do pai de Maria Amália, José Vaz de Carvalho, membro da Câmara de Deputados portuguesa, foi decisivo para que Maria Amália não somente fosse apresentada como poetisa aos mais ilustres poetas daquela época, como tivesse publicado seus primeiros versos com o aval destes, entre eles, Tomás Ribeiro e Antônio Feliciano de Castilho, seus dois primeiros padrinhos na atividade literária.

Em janeiro de 1866, às vésperas de completar 19 anos, o pai de Maria Amália passou a convidar regularmente seus colegas deputados e, também, poetas a sua casa, a fim de ouvirem e darem seu aval às primeiras poesias da filha. Desse modo, Maria Amália foi formalmente apresentada aos mais destacados membros da sociedade literária da época, em sua própria casa, publicando no ano seguinte, em 1867, o poema "Uma primavera de mulher", que marca o início de sua atividade literária.

Fazendo uso da extensa rede de sociabilidade de sua família, circunstância que seu biógrafo vai tratar como "depois de ter caído nas boas graças de muitos e distintos literatos da capital” (SILVA, 1997, p. 68), Maria Amália pôde iniciar uma carreira em um "mundo quase inteiramente masculino (androceu)". Como poetisa e, posteriormente, escritora, assinava seu próprio nome, identificando-se, sem 
necessitar do anonimato ou de esconder-se em um personagem masculino, embora vá usar alguns pseudônimos quando passa a atuar na imprensa periódica.

Desde o princípio foi aceita, porque foi levada e estimulada pela família a ocupar tal posição, o que era um apoio necessário para exercer um ofício majoritariamente masculino, naquela época. Todavia, não se pode desconsiderar aquilo a que Belline (1999) chama atenção em relação ao preconceito contra as mulheres que escreviam. Para resguardá-la da discriminação, foi preciso exaltar a sua ascendência aristocrática, a refinada cultura e a exacerbada moralidade, qualidades essas que serão suas marcas constantes, ao longo da trajetória como escritora.

Além da extensa rede de sociabilidade que avalizou a sua entrada como poetisa no mundo literário, também sua atuação como articulista de periódicos contou, mais uma vez, com o círculo familiar.

A colaboração jornalística de Maria Amália aconteceu principalmente por intervenção de seu tio Dr. Luís de Almeida e Albuquerque, director e proprietário do Jornal do Commercio-Lisboa, Lente e Director da Escola Politécnica e vereador da Câmara Municipal de Lisboa (SILVA, 1997, p. 69).

Do primeiro livro de poesias publicado em 1867, fato é que só viria a editar outra obra literária em 1876, Vozes no ermo, e se dedicaria, nesse ínterim, a escrita jornalística. Com condições absolutamente peculiares para uma mulher de seu tempo, Maria Amália escreveu para diversos jornais e revistas da época, a partir de conhecimentos e de uma vasta rede de interlocutores que também adquiria por meio de periódicos estrangeiros de que era assinante, notadamente, franceses. Entre esses jornais, em 1878,

\begin{abstract}
Maria Amália inicia uma das mais frutuosas colaborações literárias que jamais teve com um jornal, atendendo a que vivia das colunas que escrevia para os jornais. Trata-se do Jornal do Comércio do Rio de Janeiro para onde haveria de colaborar durante dezenas de anos. Em fevereiro de 1912 haveria de afirmar: 'E eu que há trinta e quatro annos dou ao Brazil o meu pensamento e quase toda a minha vida intellectual [...]' (SILVA, 1997, p. 87).
\end{abstract}

Mais do que se dedicar à publicação brasileira, Maria Amália casou-se com o poeta, nascido no Brasil, Gonçalves Crespo, com quem teve os filhos e de quem, após a viuvez precoce, em junho de 1883, herdou toda a responsabilidade sobre a família, tendo que se dedicar ainda mais à escrita para sustentar a casa, criar e educar 
os filhos. É nessa intensa produção, seja jornalística ou literária, que grande parte do seu foco será a mulher, seu comportamento, sua formação e sua educação adequada para gerir a casa, cuidar dos filhos e desempenhar os papéis reservados a ela naquela sociedade.

Diante do exposto, o presente estudo tem como objetivo analisar duas obras de Maria Amália Vaz de Carvalho acerca da educação feminina, Mulheres e Crianças: notas sobre educação e Contos e Phantasias, ambas publicadas no ano de 1880. Em um plano mais específico, é abordada a concepção da autora sobre um tema inserido nesses dois escritos, a educação doméstica, ou a educação de meninas realizada por suas próprias mães ou por mestras contratadas para esse fim. Embora Maria Amália não estimulasse a prática da contratação de mestras ou governantas para a educação de filhos e filhas, aconselhando as próprias mães a fazê-lo, em uma pequena parte de seus escritos se refere a essa prática bastante comum naquele tempo e contexto, incluindo intitular um de seus contos com essa personagem, a preceptora.

No que se refere aos aspectos metodológicos, o artigo apresenta uma pesquisa bibliográfica que tem como fontes dois livros de Maria Amália Vaz de Carvalho, as obras Mulheres e Crianças: notas sobre educação (1880) e Contos e Phantasias (1880). As publicações em pauta foram escolhidas por terem sido escritas no mesmo período e se tratarem de dois gêneros diferenciados: realidade e ficção. A primeira obra Mulheres e Crianças: notas sobre educação (1880) é um manual doméstico, ou também chamado de manual de pedagogia familiar, destinado a aconselhar o comportamento das mulheres e a ensinar como elas deviam educar as filhas. A segunda obra é o livro Contos e Phantasias (1880), que é composto por onze contos na sua parte inicial, cada um deles contendo claramente um propósito moral e educativo, destacando-se "A escolha de Gastão", "O romance de Adelina”, "Duas faces de uma medalha", "A preceptora"1 e "A morte de Bertha", que possuem personagens femininos, notadamente, relacionados aos conceitos ensejados no manual Mulheres e Crianças: notas sobre educação (1880).

\footnotetext{
${ }^{1}$ Na edição de 1880 do livro Contos e Phantasias, assim como na edição seguinte de 1905, a grafia de preceptora está colocada como "perceptora" e essa mesma grafia se estende por toda a obra. Todavia, optamos por utilizá-la de acordo com a grafia atual.
} 
Dessa forma, cotejando as obras em pauta, Mulberes e Crianças: notas sobre educação (1880) e Contos e Phantasias (1880), é possível constatar que uma das estratégias da autora em sua "missão" para educar as mulheres de seu tempo era exemplificar os ensinamentos presentes no seu manual doméstico, por meio da conduta das personagens protagonistas em seus diferentes contos. Para tanto, narrava histórias no livro Contos e Phantasias (1880) que corroboravam seus ensinamentos contidos na obra Mulheres e Crianças: notas sobre educação (1880). Cabe ressaltar que, guardados os limites da escrita de um artigo, o foco deste estudo serão os ensinamentos nas obras escolhidas de Maria Amália Vaz de Carvalho relativos à educação doméstica e o seu desdobramento sob a forma de contos, com especial atenção ao conto e às personagens cujo teor e protagonismo se referem a essa prática, sobretudo, "A preceptora".

Assim, as obras escolhidas se complementam, à medida que demonstram seja através dos ensinamentos diretos que Maria Amália oferece para as mulheres, seja por meio dos contos em que constrói narrativas que exemplificam e ilustram os seus conselhos - qual era a educação feminina e qual era o papel das mães e das mestras que ela julgava serem adequados na sociedade do seu tempo.

A fim de apresentar os resultados da investigação que remete a um estudo essencialmente documental e analítico, as obras são descritas e analisadas em dois tópicos. No primeiro deles discute-se a educação da mulher realizada pela mãe ou mestra, segundo os ensinamentos de Maria Amália contidos no livro Mulheres e Crianças: notas sobre educaşão (1880). A seguir evidencia-se a estratégia literária de Maria Amália de educar a mulher por meio de contos, com foco naqueles que tratam da educação doméstica e a sua primazia para a educação feminina, particularmente, o conto A preceptora, do livro Contos e Phantasias (1880).

Cabe notar que ao analisar os escritos de Maria Amália não se pode perder de vista a sua própria história, que terá ressonância em toda a sua obra. Rodrigues (2019, p. 15) alerta para o fato de que a sua ascendência ilustre e aristocrata criou na escritora "a apropriação de uma consciência de tutora da feminilidade", o que a faz, por vezes, olhar a condição da mulher sob preconceito, estereótipos e a partir de "padrões e ditaduras marcadas por conceitos masculinizados que fazem parte da sociedade elitizada em geral". Por outro lado, as adversidades das circunstâncias 
causadas pela decadência econômica da família, aliada ao isolamento no campo, também podem ter contribuído para torná-la uma crítica feroz de luxos extravagantes e de tudo que não esteve ao alcance de sua infância e juventude.

\section{"Educar a mulher - eis o grande problema que resta ainda resolver"}

Os livros de Maria Amália constituíam manuais domésticos destinados às mulheres de seu tempo, mas principalmente às mães de família para educar seus filhos e, sobretudo, às filhas "que liam no quarto novelas cor-de-rosa e folhetins libertinos, recheados de aventuras picantes" (SANTANA, 2009, p. 778). Em seu artigo intitulado Upstairs-downstairs: as criadas, o género e a classe no realismo português, Maria Helena Santana (2013, p. 301) vai chamar esses escritos, as crónicas de costumes, de "manuais de pedagogia familiar", os quais continham conselhos e regras para manter "a harmonia do lar” (SANTANA, 2013, p. 302).

De acordo com Cunha (2008, p. 402), referindo-se aos "manuais de civilidade", a disseminação desses escritos supunha que existisse uma comunidade de leitores, e neste caso em particular de leitoras, para que sua circulação assegurasse forjar comportamentos por meio dos ensinamentos que veiculavam, além de abalizar condutas, julgar sensibilidades, aconselhar direções de vida, constituindo-se em "uma forma de gestão de corpos e almas que encerra o indivíduo em redes de vigilância". Revestidos de narrativas simples, quase coloquiais, Cunha (2008) descreve os manuais como

vetores de sistemas de valores, ferramentas para a consolidação das formas e dos códigos morais e sociais. Eles compunham-se de inúmeros conselhos, regras precisas e orientações de conduta pessoal, moral e social, cujo objetivo era transmitir e ensinar atenções e cuidados que cada indivíduo deveria dirigir a si mesmo, no espaço público e privado (p. 405).

Ao longo de toda a segunda metade do século XIX, vai se intensificar a procura por esses "manuais para o lar", como os denomina Malta (2011, p. 43), sendo considerados indispensáveis à boa educação feminina, sobretudo àquela

\footnotetext{
${ }^{2}$ CARVALHO (1938, p. 11).
} 
realizada na esfera privada, alguns também contendo regras e receitas de economia doméstica, para ensinar às meninas, às moças e às futuras mães de família a gerir a casa (VASCONCELOS, 2018).

Um dos primeiros livros de caráter educativo, como um manual de pedagogia familiar, escrito por Maria Amália Vaz de Carvalho, cujo objetivo é dar ensinamentos sobre como educar a mulher, ou, ainda, demonstrar o comportamento feminino resultante da formação recebida, é Mulheres e Crianças: notas sobre educação. Publicado em 1880, pelos editores Joaquim Antunes Leitão e Irmão, cujo escritório funcionava na cidade do Porto em Portugal, localizado na Rua do Almada, n. 209, $1^{\text {o }}$ andar, o livro fazia parte da coleção "Bibliotheca do Cura de Aldeia”. A primeira edição era em formato de um volume pequeno, de dezenove centímetros, e possuía 312 páginas em que a autora, repetidamente, exaltava aquelas que considerava as virtudes femininas "para anular a mulher dos salões, e para criar e fortalecer a mulher de família” (CARVALHO, 19383, p. 28). Embora publicado em Portugal, havia uma menção na segunda página de que, no Brasil, a propriedade da obra pertencia ao senhor Adriano de Castro, residente no Rio de Janeiro. Na dedicatória, Maria Amália registrava o seu agradecimento à mãe, como sua única mestra: “Á minha querida mãi, companheira, constante e fiel de tôda a minha vida, ofereço êste livro humilde que escrevi inspirada pelos seus conselhos e pelo seu santo e nunca desmentido exemplo" (CARVALHO, 1938, p. 5).

Maria Amália concentra, ao longo do livro, suas críticas às mulheres das camadas médias da sociedade, embora sejam elas, notadamente, o seu público leitor. Tais mulheres cujo comportamento desaprova durante toda a escrita, ela divide em dois gêneros "acentuadamente distintos": aquelas que as vaidades ainda não corromperam e aquelas que pretendem ofuscar a sociedade com sua opulência e luxo. Apesar de um pouco mais simpática ao primeiro grupo, que para ela é composto de mulheres laboriosas, com uma "rude sensatez plebeia", detentoras do amor dos filhos e que tudo fazem para o bem-estar da família, Maria Amália diz que, ainda assim, essas mulheres são de uma "ignorância absoluta, ingênua, profunda, quási sublime na sua cegueira" (CARVALHO, 1938, p. 13). Portanto, logo estarão

\footnotetext{
${ }^{3}$ A edição com que trabalhamos neste artigo é a quarta edição, publicada em 1938 pela Editora Educação Nacional.
} 
fadadas a se transformar no segundo grupo, pois essa mulher sem conversação, sem espírito, que apenas vive para servir ao marido e aos filhos, ao ter a chance de enriquecer pelo progresso nos negócios do cônjuge, irá se transformar naquilo que Maria Amália mais condena na alma feminina: a "altiva" burguesa, cujo veneno da vaidade a ignorância deixa triunfar, e ela viverá, a partir de então, apenas preocupada em se exibir "desdenhosa, mal sentada nos flácidos coxins um coupé de oito molas, coberta de veludos e de rendas" (CARVALHO, 193, p. 17).

Maria Amália atribui as causas da ignorância feminina, que as deixaria levar pela luxúria e frivolidade, não somente à falta de educação, mas à educação superficial dada às mulheres pelas mães e preceptoras, especialmente as estrangeiras:

A influencia estrangeira e sobretudo a franceza, penetrou nas salas desbotadas dos nossos palacios e nas luxuosas residencias da nossa aristocracia moderna. Se não temos a mulher de familia, a creadora de uma geração robusta, conscienciosa, crente e leal, temos a mulher de sala, que é uma nova face da transformação lenta por que vão passando as idéas e os acontecimentos. A mulher de sala é um producto exotico entre nós. A França recebeu-a da Itália, cultivou-a, transformou-a, deu-lhe todos os requintes falsos, todos os donaires artificiaes, ergueu-lhe um throno no seio das suas côrtes galantes, e deixou que nós, vendo-a de longe a cubiçassemos e tentássemos transplantal-a para os nossos costumes chãos, para a nossa pobreza envergonhada e modesta. Sahiu-nos uma cousa hybrida e estranha, que não está em relação com o seu meio, deslocada, inútil, mas em todo o caso attrahente para os olhos superficiaes. A mulher de sala fala umas poucas de linguas, com facilidade e fluência; escreve bem, com uma certa graça adquirida que não occulta a frivolidade, mas que a envolve em véu rendilhado; conversa com vivesa e com chisto, sabe dar aos pequenos nadas da sua vida uma elegancia que illude os incautos (CARVALHO, 1938, p. 19-20).

Considerando essa uma falsa educação que em nada contribuiria com a formação das gerações futuras, Maria Amália compele a mulher a "erguer-se do marasmo intellectual em que se compraz" (CARVALHO, 1938, p. 24) e a mostrar ao homem que pode ajudá-lo na edificação do lar. É interessante notar que a autora expõe com veemência as limitações do que quer: "não pedimos para o nosso sexo a emancipação, essa utopia de que hoje se fala tanto e com tantas banalidades impensadas" (p. 28). Sua ideia de uma educação mais "robusta" é, especialmente, que a mulher deixe de lado a vaidade, as frivolidades, as sentimentalidades, e que tenha "bom senso", seja instruída com os descobrimentos e as conquistas do seu tempo, sacrificando-se aos seus deveres. 
Maria Amália demonstra claramente que o seu pensamento em relação à mulher não é de emancipação: "Longe de mim o aconselhar á mulher que se emancipe dos seus graves e obscuros deveres, que tente luctar com o homem, e arrancar-lhe a palma das grandes descobertas e das grandes conquistas!" (CARVALHO, 1938, p. 166). Sua pretensão é limitada a que deixe de existir a "mulher de sala" e surja no seu lugar a "mulher da família", voltada unicamente para os seus deveres de esposa, dona de casa e mãe. Para isso, ela deveria ser "profundamente instruída", mas essa instrução não poderia afastá-la dos seus deveres da casa e da maternidade, que englobavam ser a enfermeira dos doentes da família, a administradora dos gêneros e suprimentos, a vigilante do asseio de todos, além de ser a mãe "carinhosa, dedicada, capaz dos máximos e dos mais perseverantes sacrifícios" pelo marido e filhos (CARVALHO, 1938, p. 167). Esse deveria ser o principal trabalho da mulher e não fazer crochê, bordar e cozer durante anos as mesmas peças (p. 167).

Como se verifica ao longo de todo o manual, Mulheres e Crianças: notas sobre educação, Maria Amália, em sua escrita, é extremamente severa com as mulheres, e apresenta uma visão crítica de tudo que as envolvia dentro e fora das casas, desde o vestuário até a realização dos mais modestos saraus. Ela mesma se refere a sua posição:

\begin{abstract}
Teem-me dito por varias vezes que eu sou feroz para com o sexo a que pertenço; que accuso com muita injustiça as mulheres de todos os males que teem succedido, que succedem ou que estão para succeder no nosso mesquinho planeta. Ora eu, pelo contrario, estou convencida de que o meu orgulho, de que a minha vaidade feminil me levam a dar ás mulheres uma importancia que mais ninguém thes quer reconhecer. Eu digo que d'ellas provêem todos os males, porque estou convencida - talvez sem razão - que d'ellas podiam provir todos os bens. Ainda no ponto de que se tracta é d'ellas toda a culpa, no meu humilde entender (CARVALHO, 1938, p. 38).
\end{abstract}

Ainda na mesma justificativa, para ela, os "pobres maridos" eram defendidos por terem que se submeter aos caprichos das esposas "burguesas" que gastavam todo o dinheiro, adquirido com muito trabalho, em uma "toilette falsamente luxuosa", em uma "soirée" ou em um jantar de cerimônia, onde cada uma pretendia figurar mais rica que a outra. Assim, a vida do casal não teria felicidade e harmonia, pois segundo Maria Amália advertia: "O homem trabalha para dar o bem-estar á mulher, e rouba para lhe dar o luxo!” (CARVALHO, 1938, p. 42). Quanto ao 
interior das casas, a autora descrevia o que generalizava como sendo o protótipo dos lares das mulheres vaidosas e ricas de sua época:

\begin{abstract}
Nada mais fúnebre, mais triste, mais sombrio do que o interior de uma d'essas casas, em que o necessário é sacrificado ao supérfluo, em que o real é sacrificado ás apparencias, em que o conforto intimo é sacrificado ao apparato exterior. As criadas sujas, despenteadas, petulantes; as creanças pallidas, anemicas, sem educação e sem solas; com os dentes podres e nodoas no vestido; os moveis indiscretos na mal disfarçada miséria, uma única casa elegante - a sala - falsa taboleta de uma vida de imposturas; a roupa branca do marido encardida e grosseira, a toilette da mulher vistosa e mirabolante. As cores tapageuses, substituindo a qualidade fina e solida; a multiplicidade dos arrebiques, substituindo a simplicidade opulenta do trajo. Quem depois de conhecer dous annos estas galés conjugaes, se resigna a viver n'ellas? Os pequenos preferem o collegio sordido e brutal; o homem foge para o botequim ou para outros sitios peiores; a mulher vive na rua, na modista, no theatro, nas salas do seu conhecimento, no passeio, na ociosidade e depois Deus sabe em que! (CARVALHO, 1938, p. 40).
\end{abstract}

Para quem foi educada pela mãe, a escolha do colégio era a demonstração da completa incapacidade de se encarregar da formação dos filhos e filhas. A autora não tinha dúvida, só havia um remédio para todos esses males: transformar a educação da mulher e ela se instruir "unicamente para o interior da sua casa" (CARVALHO, 1938, p. 41). Para que o tédio e a melancolia não a acometessem, recomendava os livros, a boa música, as flores e o trabalho doméstico. O importante era se afastar do luxo, das ambições, das "mesquinhas invejas", que corroíam as forças da mulher e que corrompiam os costumes e os sentimentos na família e na sociedade, desviando-a do ideal de ser "boa esposa, boa mãe, boa dona de casa" (CARVALHO, 1938, p. 44).

Todos os males que assolavam a família e a sociedade, segundo Maria Amália, eram fruto da falta de uma educação feminina "sólida e positiva" e, para tanto, tornava-se imperioso modificar a que existia, radicalmente. De acordo com a autora, a mudança deveria começar pelos ensinamentos que, embora considerados parte integrante de uma educação perfeita, deveriam ser suprimidos, pois eram nocivos ou inúteis, ou ainda, promoviam a vaidade e a luxúria. Entre esses misteres que precisariam deixar de ser ensinados estariam a dança, tratada por ela como "um talento absolutamente dispensável", que só serviria para estimular a coquetterie e o desejo de exibir-se; e a tapeçaria, que promoveria a "hypocrisia da preguiça", dando 
tempo ao pensamento para, desocupado, buscar um ideal impossível. O piano também fazia parte das críticas, pois para Maria Amália nem todas as filhas teriam talento para essa arte e obrigá-las a tocar era "atormentar com elle o ouvido do próximo" (CARVALHO, 1938, p. 49). Para a autora, os ensinamentos que deveriam permanecer sendo oferecidos às mulheres eram a música, a história, as línguas, a geografia, a aritmética, as ciências naturais, a botânica, a mineralogia, a biologia, entre outras ciências dessa natureza.

Sempre se referindo a uma educadora que estaria junto à criança, uma governanta ou preceptora, Maria Amália alerta para o fato de que se ela ou a mãe percebessem talento para alguma atividade intelectual na filha ou discípula, deveriam estimulá-lo para que essa vocação fosse desenvolvida. No entanto, sua maior preocupação era que a educação não fosse uniforme para todas as crianças e jovens, e muito menos "uma questão de moda, uma questão de vaidade, uma questão de mútua inveja mesquinha" (CARVALHO, 1938, p. 50). Nesse sentido ela exemplificava o costume, muito em voga na época, de aprender línguas, especialmente quando se tratava da educação a cargo de preceptoras estrangeiras. Segundo Maria Amália:

As linguas são hoje ensinadas com muito esmero. Mas que applicação se dá a essa scicncia adquirida em muitos annos de estudo e de pratica? Uma applicação deveras ridícula! Entre vinte das meninas que sabem hoje francez, inglez, allemão ou italiano, não ha quatro que tenham lido Hugo ou Bossuet, Eacinc ou Montaigne, Shakspeare ou Milton, Goethe ou o Dante, não ha quatro sobretudo que estejam aptas para comprehenderem estes mestres do pensamento e da palavra (CARVALHO, 1938, p. 51).

Somente realizando a educação com base nos ensinamentos indicados em seu manual e com o exemplo das mães, Maria Amália acreditava ser possível tornar as filhas aptas a exercer o "sacerdócio" de esposas, da maternidade e de donas de casas. Para a autora, a grande preocupação das mulheres deveria ser com a velhice e no livro Mulheres e Crianças: notas sobre educação (1880) ela dedica o capítulo três a esse tema: "A velhice das mulheres". A argumentação desenvolvida gira em torno da dependência feminina do casamento ou de sustentação parental e na falta dessas condições, de como irá prover o próprio sustento. Nessa perspectiva, lista algumas profissões que a mulher educada poderia vislumbrar e que seriam aceitas na 
sociedade para não ter que se submeter a uma "funesta dependência" de um casamento arranjado, de ficar sob a sujeição de parentes ou, ainda, "perder-se". Entre as profissões listadas a mais atraente é "ensinar línguas, ensinar música, ensinar e explicar as sciencias que houvesse aprendido, a historia, a arithmetica, a litteratura, a geographia" (CARVALHO, 1938, p. 61). Contudo, a autora alertava que a educação que as mulheres recebiam não as preparava para as vicissitudes da vida e nem para as necessidades ocasionadas pelas adversidades, já que os ensinamentos femininos não passavam de frivolidades, cuja culpa era das mães que não sabiam educar suas filhas.

É nessa perspectiva que Maria Amália abre o quinto capítulo do seu livro, intitulando-o "As mães e as filhas". Para a autora, toda a culpa da falta de educação das filhas era das mães, que enviavam os filhos homens para os colégios, mas mantinham em seu convívio as filhas mulheres. Ao invés de darem a elas uma educação adequada, despertavam-lhes a vaidade e a inveja por meio das únicas preocupações que apresentavam, sejam relativas à beleza ou à riqueza:

Desde a burgueza, que, apenas sabe dos desfiladeiros sombrios da miséria, já cuida tão sómente em hombrear com as duquezas que inveja de longe, até á mais aristocratica descendente das antigas paladinas, todas teem as mesmas noções falsíssimas ácerca da educação que suas filhas devem receber (CARVALHO, 1938, p. 88).

Descrevendo essa educação superficial que só causaria danos, Maria Amália diz que eram chamados professores de dança, de música, de línguas, de desenho, ou, como outra opção, menos utilizada, conduzia-se a menina ao colégio mais afamado para aprender prendas deste gênero. Além disso, era ensinado a ela bordar a lã, bordar a ouro, bordar sobre escomilha, fazer crochê, flores, pequenos trabalhos de agulha etc. Raras eram as famílias "mais dadas à sciencia”, que escolhiam para suas filhas ensinamentos de geografia, "alguma história sagrada e profana, uma leve tintura de arithmetica" (CARVALHO, 1938, p. 91). Combinando as prendas com um pouco de doutrina cristã, "aos quinze annos a menina preparada por estes elementos tem a sua educação completa” (p. 91).

Cabe ressaltar que, embora tenha como referência as camadas médias e mais favorecidas economicamente da população, Maria Amália assegura que essa educação superficial pode ser observada em todas as mulheres com acesso aos 
meios letrados do Portugal de seu tempo. Educação que, para ela, não era útil ou conveniente a nenhuma "classe da sociedade":

Quer seja filha de um duque, quer seja filha de um fabricante, quer o seu destino a reserve para receber n'uma sala faustuosa os altos personagens da política e da diplomacia, para fazer parte da corte, para conviver num pé de intimidade com todos os grandes, e com todos os opulentos; quer ella tenha do partilhar as luctas obscuras de um modesto empregado, de um industrial de poucos haveres, de um artista desprotegido, é a mesma a sua educação moral, physica e intelectual (CARVALHO, 1938, p. 91).

Essa educação feita ao longo dos anos de conhecimentos inúteis, não permitiria à mulher estar preparada para resistir às tentações, às adversidades, às misérias e aos combates da vida. Na primeira edição do livro Mulheres e Crianças: notas sobre educação, publicado em 1880, Maria Amália propõe, para reverter essas circunstâncias, a criação de uma "escola-modelo, onde a creança aprendesse a ser mulher, onde a mulher aprendesse a ser mãe!” (CARVALHO, 1880, p. 99). Entretanto, esse parágrafo desaparece nas edições posteriores. Essa supressão, provavelmente, foi feita pela própria autora, o que pode ser explicado por não ser a escola, pelo menos um determinado tipo de escola para moças, a preferência de Maria Amália para a educação das filhas. Essa constatação faz-se logo no capítulo a seguir, intitulado "As dactas d'uma vida", que inicia com a ida para o colégio da jovem Lili.

O colégio de Madame Maubry, uma "francesa elegantíssima”, vai ser descrito por meio do diálogo dos pais da menina, para adiante, ser sugerida sua má influência sobre as etapas importantes da vida de Lili, narrada desde a primeira comunhão, a ida aos bailes, o casamento de conveniência, a condição já como condessa e a velhice, na qual sente a solidão e o arrependimento por não ter aprendido a ser filha, nem amante, nem esposa, nem a mãe que deveria ter sido.

$\mathrm{Na}$ segunda parte do livro Mulheres e Crianças: notas sobre educação, que Maria Amália intitula de Criados e Amos, é a seção da obra em que ela, pela primeira vez, vai falar, mais detalhadamente, de colégios e das mestras de meninas. Até então havia apenas se referido a exemplos de governantas estrangeiras, especialmente inglesas, que contribuiriam na educação considerada precária por ela: "[A condessa] tem duas filhas... que uma governante inglesa educa e acompanha” (CARVALHO, 1938, p. 125). 
Um estudo recente sobre as criadas no último século português, escrito por Inês Brasão (2012, p. 10), O tempo das criadas, sugere que ainda se deu pouca atenção "ao peso explicativo que os processos da subalternidade têm para o formato da vida contemporânea e para as estruturas da sociedade”. O lugar onde Maria Amália inclui sua menção às mestras e, nesse caso, também, às governantas que se encarregavam da educação das meninas diz muito sobre a condição dessas mulheres na sociedade da época, na estrutura da casa e na subjetividade do seu lugar dentro da própria família: era mais uma "criada", embora dotada de instrução, pela qual tinha sido contratada. Santana, sobre o assunto, adverte:

Maria Amália Vaz de Carvalho, que muito escreveu sobre a vida doméstica burguesa, resume a questão de forma lapidar: 'Provado está que os criados são os nossos inimigos necessários, e que é preciso que para com eles a nossa atitude seja, por enquanto, inteiramente defensiva' (SANTANA, 2013, p. 302).

Para Maria Amália essas relações teriam chegado a este estado por não haver mais empregos estáveis passados de geração em geração, onde as filhas "da aia, ou varredora, ou engomadeira” ocupavam o lugar de suas mães, que só deixavam a casa aos "60 ou 80 annos no caixão para o cemiterio, deixando na familia nova geração de servos que eram seus filhos" (CARVALHO, 1938, p. 200). Ao se romperem esses laços e os novos "grandes financeiros modernos" - forma como a autora trata os ricos - tornarem os criados facilmente substituíveis, era de se esperar, na opinião de Maria Amália, que eles usassem de diversas artimanhas para preservar o emprego.

No dia em que a aia recebe a primeira confidencia da senhora, no dia era que entrega o primeiro bilhete, no dia em que lhe é escutado o primeiro recado de que a encarregam, invertem-se os papeis, e só continua apparentemente aquella humildade que a suffocava de cólera e de despeito. Era escrava obediente e muda, hoje é cúmplice, o que quer dizer tyranna (CARVALHO, 1938, p. 204).

Procurando sempre localizar os culpados das circunstâncias que aponta, no caso das criadas mal educadas e prontas a explorar as patroas estaria a falta de instituições educativas, tanto mantidas pela iniciativa dos particulares como pela iniciativa do Estado, os asilos de caridade, de onde poderia prover a maior parte das órfãs e meninas desamparadas para empregarem-se nas casas como criadas, tendo uma educação adequada. No entanto, segundo Maria Amália, as instituições 
existentes desse porte eram poucas e limitavam-se a ensinar a ler, escrever, contar, coser, marcar, bordar de branco, bordar de missanga, bordar com cabelo, fazer crochê, tocar órgão e, em algumas, a gramática, história, geografia, etc. Assim, de cada cem, nas palavras da autora, apenas dez meninas, mais tarde, aproveitariam desse gênero de estudos, com inteligência para se tornarem mestras régias, caixeiras de alguma pequena loja ou "mesmo professoras particulares se houverem progredido no estudo e adquirido uma instituição mais solida e mais profícua" (CARVALHO, 1938, p. 212-213). Quanto às outras noventa que não teriam o destino de mestras, afirma:

São as criadas de hoje, ou serão as criadas de amanhã. A educação que lhes deram está em contraposição perfeita com a tarefa que teem de cumprir. Uma que foi apresentada para cosinheira, não tem as minimas noções culinarias, mas em compensação lê correctamente os jornaes que veem de manhã. Outra, cuja obrigação é engommar, não tem geito senão para bordar de matiz. Algumas, menos favorecidas da intelligencia, não sabem o que aprenderam, nem aprenderam aquillo que fazem. São as mais vulgares! (CARVALHO, 1938, p. 214-215).

Maria Amália faz uma distinção explícita entre a educação que deveria ser dada às "raparigas do povo", nos asilos de beneficência e nas escolas de mestras. Aquelas que não demonstrassem disposição para trabalhos mais elevados deveriam receber uma educação voltada para o seu "futuro papel" na sociedade, "de criadas", devendo ser ensinado a elas a leitura, a ortografia e alguns elementos de aritmética; já as que demonstrassem "manifestações inequívocas de claro e perspicaz entendimento" deveriam ir para uma casa de educação que as preparasse para serem "futuras professoras, ou futuras artistas".

\begin{abstract}
Haveria n'esse estabelecimento mestras ou mestres que a cada uma conforme a sua vocação ensinassem as linguas, a musica, a pintura em porcellana, a grammatica, a geographia, a contabilidade, etc., etc. A essa casa, que devia ser subsidiada pelo governo e auxiliada pela bolsa particular, iriam as mães de família procurar professoras portuguesas, para as suas filhas, professoras cuja educação fosse completa, e cuja moralidade podesse ser afiançada (CARVALHO, 1938, p. 215-216).
\end{abstract}

Evidencia-se não somente a crítica da autora a um ensino comum às filhas das camadas mais desvalidas da população, assim como às professoras estrangeiras que atuavam como preceptoras e governantas nas casas portuguesas, cujo passado e 
moralidade era, muitas vezes, desconhecido. Cabe notar a contradição em relação às mulheres estrangeiras, quando ao explicar detalhadamente como seria a escola de criadas, tão importante de ser instituída quanto a escola de mestras, Maria Amália assegura que as primeiras professoras a atuar nessa escola deveriam ser escolhidas inicialmente "nos países estrangeiros" e, somente depois, deveriam ser as próprias alunas educadas no asilo a se tornarem mestras.

Em que pese a afirmação de Lopes (2005, p. 574) de que "qualquer presença afirmativa incomoda Maria Amália", e de que ela teimava em repetir o passado, aprisionando a mulher ao interior de sua casa já iniciado o século XX, a sua escrita, por meio dos manuais de pedagogia familiar e dos contos, alcançou diferentes gerações e promoveu alguma modificação na condição feminina, especialmente das mulheres que estudavam e ensinavam a partir de seus livros, sobretudo, as mestras infiltradas nas casas da burguesia e da aristocracia que, de alguma forma, ao ler e contar as histórias da autora provocaram senão mudanças, ao menos reflexões.

\section{A mulher nos contos: a estratégia educacional de Maria Amália}

Os ensinamentos que Maria Amália Vaz de Carvalho oferece dirigindo-se diretamente a suas leitoras na obra Mulheres e Crianças: notas sobre educação, ela transforma em exemplos através de contos, publicados na mesma época, 1880, no livro Contos e Phantasias. O livro Contos e Phantasias, além de publicado no mesmo ano, terá o mesmo editor e endereço de sua outra obra, Joaquim Antunes Leitão, cujo escritório funcionava na cidade do Porto em Portugal, localizado na Rua do Almada, n. 209, $1^{\circ}$ andar, e também fazia parte da coleção "Bibliotheca do Cura de Aldeia". A diferença desta publicação para Mulheres e Crianças: notas sobre educação está no fato de que, em Contos e Phantasias, Joaquim Antunes Leitão subscreve a publicação sozinho como editor, sem o irmão, como havia sido no manual de pedagogia familiar, na qual utilizam o monograma L.\&I., referente a Leitão e Irmão. Em Contos e Phantasias, o monograma que vai ilustrar a publicação é J. A. L. relativo às iniciais do editor apenas. 
A primeira edição de Contos e Phantasias tinha o formato semelhante à sua congênere da mesma autora, com dezenove centímetros, e possuía um total de 319 páginas. O livro é dividido em duas partes, sendo que a primeira contém onze contos, quais sejam: "Uma história verdadeira"; "O tio Sebastião"; "O annel do diplomata"; "A escolha de Gastão"; "O romance de Adelina”; “A Cigana”; "Duas faces de uma medalha"; "A tia Izabel"; "O melhor somno do milionário"; "A preceptora"; e "A morte de Bertha". Na segunda parte há quatro ensaios, em que a autora se dirige diretamente aos leitores, nos quais faz uma análise do tempo vivido e traça um escopo biográfico de Madame de Balsac, Lincoln e Grant, finalizando $\operatorname{com}$ As filhas de Victor Hugo.

Com Contos e Phantasias (1880), Maria Amália cercava seu público de todas as maneiras. Àquelas que não haviam compreendido seus conselhos de modo explicativo no manual de pedagogia familiar, Mulheres e Crianças: notas sobre educação, teriam exemplos narrativos em contos semelhantes a crônicas cotidianas, as quais buscavam provar os efeitos maléficos da má educação feminina, ou da educação supérflua, baseada em frivolidades. Santos (2011, p. 34), em sua pesquisa, explicita o uso da obra literária para interrogar as normas, os valores e os princípios estabelecidos, pretendendo até mesmo substituí-los por outros.

Neste sentido, deveremos considerar a obra literária em geral e a ficcional em particular como um laboratório permanente de sacralização e de reestruturação dos valores de uma sociedade, na medida em que o herói, personagem que veicula um certo número de qualidades positivas (e/ou negativas), permite ao leitor 'reconhecer-se' nele - já que a 'crença' do sujeito de leitura passa pela aceitação do valor do protagonista -, criando-se assim uma espécie de acomodação do texto ao seu destinatário. Conclui-se, então, que um dos objetivos primordiais e explícitos da narrativa ficcional é o de enunciar "positividades" e "negatividades", isto é, de manter ou contestar os sistemas de princípios estabelecidos na sociedade (SANTOS, 2011, p. 34).

Assim, ao transformar os ensinamentos em contos, Maria Amália utiliza cenários muito comuns ao cotidiano da época, para demonstrar que a heroína que segue rigorosamente os seus conselhos sempre é premiada, tendo como final feliz a harmonia do lar, enquanto aquela que os descarta é punida. Como resume Belline (1999, p. 48), "trata-se de transformar em narrativa, construindo um personagem 
concreto, as abstrações sobre uma mulher idealizada que se anula diante do homem para quem vive exclusivamente, sem qualquer anseio pessoal".

Na mesma linha, Martini (2016, p. 126) descreve como, no conto "A morte de Berta", a autora vai usar a narrativa ficcional para enfocar o tema do adultério, causado pela insatisfação feminina, contando-o a partir dos "olhos de uma criança". A mesma lógica utilizada nos conselhos dados em Mulheres e Crianças: notas sobre educação é agora aplicada a uma história corriqueira. O pai, a vítima, bondosa e trabalhadora, tudo fazia para sustentar a família, até que descobre, por meio de um descuido da filha, a traição da mãe, mulher egoísta que não preservou sua família. Essa é a conclusão que se desprende da narrativa da autora. Martini complementa que "ao inserir a criança na dinâmica familiar, partilhando, inclusive, o maior temor da burguesia, Maria Amália busca, intencionalmente, passar uma mensagem aos adultos, que são os principais responsáveis pelo cultivo dos relacionamentos" (MARTINI, 2016, p. 128).

No conto "A escolha de Gastão", Santos (2011, p. 38) alerta para o fato de que “a ideia da fragilidade biológica feminina obrigava-a a ficar confinada a espaços privados e a dedicar-se à família”. No entanto, isso não significava ser destituída de influência sobre os homens, como mostra o conto "A enjeitada"4. Ao contrário, segundo Santos (2011, p. 38), Maria Amália acreditava que, se bem orientadas, as mulheres "tinham o poder de 'conduzir' os homens que as escutassem, que tivessem em conta os seus conselhos e que apreciassem os seus discursos". Contudo, essa orientação envolvia submissão, desfaçatez e um rigoroso cumprimento dos deveres matrimoniais.

No conto "Duas faces de uma medalha", Maria Amália irá questionar a escolha de Margarida, que, para não contrariar a vaidade do pai, casa-se com o pretendente eleito por ele, um conde, abandonando aquele a quem ela amava, um rapaz jovem e trabalhador. O conde esbanjador acabará com a fortuna da esposa, "deixando-a com dois filhos na miséria, o que a obriga a dar lições em Lisboa, para os sustentar" (SANTOS, 2011, p. 149). Maria Amália, por meio do conto, demonstrava o teor do castigo de sucumbir à vaidade:

\footnotetext{
${ }^{4}$ Este conto, "A Enjeitada", não está na obra Contos e Phantasias de Maria Amália Vaz de Carvalho, mas em Serões no Campo, publicada em Lisboa, Typ. Mattos Moreira, 1877, p. 194.
} 
Dava lições! A brilhante Condessa de V..., a filha adorada de um dos homens mais ricos de Lisboa, a rainha dos salões luxuosos, a estreita mais fulgurante do alto mundo, dava lições para sustentar os dous filhos que lhe restavam, unicos vestígios de um passado de pomposas mentiras. [...] Levantava-se de manhã muito cedo, bebia á pressa uma chicara de café, que a sua fiel Miss Brown, companheira dos triumphos e das desventuras lhe preparava por suas proprias mãos, e sahia, modestamente vestida de preto, a cumprir a sua improba tarefa. Só voltava a casa de noite. Divulgára-se rapidamente a noticia d'aquella excepcional desventura, e muita gente, que vira com desprazer a prodigalidade da caprichosa condessa, compadecia se agora, sem pensamento reservado, d'aquella digna e santa expiação. Margarida tinha muitas discipulas (CARVALHO, 1905, p. 168-169) ${ }^{5}$.

Além desse exemplo, no conto "O romance de Adelina", ela adverte, através da personagem, que após a má conduta, a partir da tomada de uma decisão impensada, não adiantava mais queixar-se, diz a personagem: "Quando estou só, estremeço ás vezes com um asco intraduzivel de mim propria. Quem é que se consola das maculas de um tal amor?" (CARVALHO, 1905, p. 135).

No que tange à preceptoria, essa era uma das poucas ocupações, a de governanta de meninas, elencada sem veementes críticas por Maria Amália no seu manual de pedagogia familiar. Contudo, a ocupação descrita nos contos vai estar sempre relacionada a algum tipo de abandono sofrido pela mulher que é obrigada a exercê-la, tratando-se de uma punição.

Na sociedade tradicional, o único emprego que uma jovem ou uma senhora podia ocupar, sem perder reputação, consistia em fazer para outrem o que teria feito por si mesma se tivesse tido essa possibilidade: educar crianças, em relação a quem, no entanto, Ihe é interdito nutrir qualquer forma de amor. Maria Amália Vaz de Carvalho confirma-o através de Mrs Wilson, de "A Enjeitada", que, no seu colégio, recebe "meninas felizes e amimadas em casa de seus pais, [mas] de quem ela não podia ser mais do que a preceptora" (SANTOS, 2011, p. 343).

A preceptoria era a maneira mais utilizada pelas camadas da burguesia e da aristocracia para a educação doméstica de suas filhas, tanto em Portugal, como no Brasil, no século XIX (VASCONCELOS, 2005). Considerava-se uma ocupação reconhecida e aceita para mulheres preferencialmente solteiras que precisassem ganhar o próprio sustento. Para tal função de educar meninas nas casas, as famílias

\footnotetext{
${ }^{5}$ A edição com que trabalhamos neste artigo é a segunda edição, publicada em 1905, pela Livraria Editora, Parceria António Maria Pereira, localizada em Lisboa, Rua Augusta, n. 50, 52 e 54.
} 
davam preferência a mulheres estrangeiras, inglesas, alemãs e francesas, tidas como mais capacitadas por terem estudo em instituições escolares específicas, também para esse fim, em seus países de origem, e por dominarem as línguas em voga na época. Vasconcelos (2018, p. 293) evidencia que, por vezes, o simples fato de ser "alemã, francesa ou inglesa era referência suficiente das habilidades para a contratação", não se exigindo nenhuma outra comprovação de estudos às candidatas ao cargo.

\begin{abstract}
Assim, a maneira mais prática para reparar ou suprir essa lacuna na família era buscar [...] no reino das governantas, professoras, preceptoras, tanto no interior da Inglaterra, em Paris, ou nos territórios germânicos, mulheres capazes de, sem correr o risco de testemunharem para a sociedade local o estado em que encontraram as crianças e mesmo a casa, tornarem as meninas educadas para a apresentação pública, o casamento e a gestão do lar, a ponto de serem lisonjeadas em suas maneiras e caprichos, moldados por uma artífice estrangeira (VASCONCELOS, 2018, p. 300).
\end{abstract}

Todavia era muito tênue o limite do lugar que essas preceptoras ocupavam nas casas, uma vez que não eram simples criadas, mas também estavam muito longe de serem tratadas como membros da família, ensinamento esse que Maria Amália faz com veemência, ou seja, a necessidade de se manter distância das "criadas", aí incluídas as aias, governantas e preceptoras (VASCONCELOS, 2005; 2007).

O conto "A preceptora" é revelador da subjetividade presente nessa função. A protagonista que exerce tal ofício é Martha de Vasconcellos, filha bastarda de um homem "extremoso" que provê sua educação desde criança, mas não pode reconhecê-la, porque cometeu com o seu nascimento "uma historia deploravel, a historia do seu crime!", a infidelidade para com a sua legítima esposa (CARVALHO, 1905, p. 209). Maria Amália descreve Martha já como preceptora na casa do comendador Gonçalves. Atribui a ela as características de ser alta, com cabelos loiros e crespos, vestida de branco, e de ter o "olhar azul, meigo e pensativo" de uma criança despreocupada, mas alertando que isso era apenas uma aparência, pois: "quem a conhecesse de perto sabia que ella tinha a seriedade precoce dos que já padeceram muito" (CARVALHO, 1905, p. 203). Daí em diante, a "mesquinhez do seu destino" e o sofrimento imputado a sua vida de preceptora são descritos nas pequenas humilhações que sofre no seu dia a dia junto às discípulas filhas do comendador. As 
alunas eram exemplos revestidos de tudo aquilo que Maria Amália condenava no manual anterior, "burguezinhas pretenciosas", vaidosas, invejosas, fúteis e frívolas, além de tratarem a Martha com desdém "quase brutal". Pagavam-lhe pelos serviços e cobravam integralmente por eles, desde tocar piano durante toda a soirée até ensinar qualquer modismo do qual tomavam conhecimento.

Para Maria Amália a situação de ter que se submeter a trabalhar para moças caprichosas, fora da sua própria casa, era descrita como um cenário de dor e amargura, e servia como um alerta das punições que sofreriam as mulheres que se desviassem do comportamento adequado pelas tentações da vaidade. "Destino ingrato", “indiferença cruel”, “infortúnio”, "coração despedaçado”, "sonho desfeito", "dilacerante agonia", "grandes comoções" são algumas das palavras que levam ao desfecho final do conto, no qual Martha ingenuamente se apaixona pelo filho do comendador e a autora vai mostrar às mulheres de seu tempo que deveriam limitar seus sonhos, ter humildade e ausência de aspiração até nos pensamentos, conforme os ensinamentos contidos em Mulheres e Crianças: notas sobre educação.

Como não poderia deixar de ser para um conto que não era de "fadas", mas muito distante disso, Julião, o filho do comendador, vai ter o casamento arranjado com a filha de um barão para unir as riquezas e os títulos das famílias, restando a Martha o "silêncio angustioso e profundo", tendo ainda o castigo de continuar a conviver com as filhas do comendador, com o homem que amava e a sua noiva.

Em todos os contos, em doses maiores ou menores, Maria Amália vai alertar as leitoras dos "perigos das paixões" (MARTINI, 2016), construindo uma narrativa cuja mensagem é, essencialmente, revestida de cunho pedagógico para chamar atenção das mulheres aos limites dos seus papéis como esposas, donas de casa e mães.

\section{Considerações finais}

Maria Amália fez parte de uma geração de mulheres que nasceu em Portugal e ganhou notoriedade em fins do século XIX e que, como no resto da Europa, passou a reivindicar publicamente, através de seus escritos, maior e melhor educação para as mulheres. Essas escritoras, como apresentam Vicente e Vicente (2015, p. 
41), pertenciam sobretudo às elites, que "geralmente, não tinham tido acesso a qualquer tipo de educação formal, antes fruindo de circunstâncias específicas, quase sempre ligadas à condição e empenho familiar", ou seja, elas mesmas tendo sido educadas pela mãe ou por preceptoras. O esforço dessa geração contribuiu enormemente para colocar a mulher em pauta, ainda que suas expectativas tivessem que se adaptar a um paradigma masculino, que permitia pouco espaço de movimento, além de conquistas lentas, intercaladas por diversos retrocessos.

Assim, embora vivesse em uma época assinalada pelo sufragismo emergente, Maria Amália aceitava “como 'naturais' as profundas diferenças marcadas pelo género". Seu ativismo era muito mais pela educação da mulher para ser boa esposa, dona de casa e mãe do que qualquer outra conotação política ou social. Ainda que o movimento feminista em Portugal por volta dos anos de 1900 apontasse que a solução estava em "fundar escolas, libertar as futuras gerações femininas da ignorância e da superstição, de preconceitos mesquinhos e de prevenções dogmaticamente incutidas, pregar-lhes o evangelho do trabalho" (VICENTE; VICENTE, 2015, p. 42), as expectativas de Maria Amália eram bastante mais limitadas, incluindo críticas às feministas que proferiam discursos inflamados sobre suas posições.

Entre as suas primeiras manifestações literárias, datadas de 1880, estão os ensinamentos contidos no manual de pedagogia familiar Mulheres e Crianças: notas sobre educação, cujos conselhos são também apresentados sob a forma de contos, como uma estratégia que Maria Amália utiliza para, de uma forma ou de outra, convencer as mulheres de seu tempo da importância de uma vida simples, sem vaidade, sem luxo, sem desperdícios, voltada unicamente para a casa, o marido a criação dos filhos e a harmonia da família.

Nessa luta que trava intensamente, tendo como arma a pena e o papel, utiliza o discurso direto para aquelas que pode convencer apenas aconselhando. Todavia, às mais resistentes vai demonstrar através dos contos o triste fim daquelas que não ouviram os seus ensinamentos, considerando como uma verdadeira punição, cercada de sofrimento, a vida de preceptoras, mestras andarilhas que tinham que ensinar pelas casas de suas discípulas. 
De acordo com Belline (1999, p. 50), no final da década de 1890, Maria Amália, em um artigo escrito para a Revista $A$ Mensageira, uma publicação brasileira destinada ao público feminino, teria reconhecido a "evidência e verdade" da doutrina feminista, "pois percebeu que 'ao egoísmo brutal do homem repugna instintivamente a superioridade mental da mulher"'. Contudo, o reconhecimento e a visão que, provavelmente, passou a ter com as mudanças que foram ocorrendo no limiar do novecentos não alteraram substancialmente seus livros, que continuaram a ser editados nas décadas seguintes, com pouquíssimas supressões e mudanças quase imperceptíveis.

\section{Referências}

BELLINE, A. H. C. Júlia Lopes de Almeida e Maria Amália Vaz de Carvalho: vozes femininas? Via Atlântica, n. 2, p. 41-57, 21 jun. 1999.

BRASÃO, I. O tempo das criadas. A condição servil em Portugal (1940-1970). Lisboa: Tinta-da-China MMXII, 2012.

CARVAlHO, M. A. V. Contos e Fantasias. 2. ed. Lisboa: Parceria António Maria Pereira, 1905. (1. ed: Porto: Joaquim Antunes Leitão, 1880.)

CARVAlHO, M. A. V. Mulheres e Crianças: notas sobre educação. 1. ed. Porto: Joaquim Antunes Leitão \& Irmão, 1880.

CARVALHO, M. A. V. Mulheres e Crianças: notas sobre educação. 4. ed. Porto: Editora Educação Nacional, 1938.

CUNHA, M. T. S. Tenha Modos! A correspondência em manuais de civilidade e etiqueta (Anos 1920-1960). In: RAMOS, A. F.; PATRIOTA, R.; PESAVENTO, S. J. (Orgs.). Imagens na história. São Paulo: Aderaldo \& Rotschild, 2008. p. 398-411.

LOPES, A. M. C. Imagens de mulher na imprensa feminina de oitocentos. Percursos de modernidade. Lisboa: Quimera, 2005.

MALTA, M. O olhar decorativo: ambientes domésticos em fins do século XIX no Rio de Janeiro. Rio de Janeiro: Mauad X, Faperj, 2011.

MARTINI, E. F. Quem paga a conta? Questões de família segundo Fialho de Almeida e Maria Amália Vaz de Carvalho. Revista Diálogos Mediterrânicos, n. 11, p. 116-130, dez. 2016. Disponível em: http://www.dialogosmediterranicos.com.br/index.php/RevistaDM/article/view/215 Acesso em: 16 jun. 2020.

RODRIGUES, P. S. S. A educação feminina e a caridade em Maria Amália Vaz de Carvalho Uma perspectiva social. 2019. 105 p. Dissertação (Mestrado em Estudos Românicos) — Faculdade de Letras, Universidade de Lisboa, 2019. 
SANTANA, M. H. O romance português dos anos 1930: retratos femininos. In: CONGRESSO INTERNACIONAL DA ASSOCIAÇÃO BRASILEIRA DE PROFESSORES DE LITERATURA PORTUGUESA - ABRAPLIP, 22., 2009, Salvador. Anais... Salvador: UFBA, 2009. p. 776-787.

SANTANA, M. H. Upstairs-downstairs: as criadas, o género e a classe no realismo português. In: LOURENÇO, A. A.; SANTANA, M. H.; SIMÕES, M. J. (Coords.). O Século do romance: Realismo e Naturalismo na ficção Oitocentista. Coimbra: Centro de Literatura Portuguesa, 2013. p. 301-310. Disponível em: https:/ / estudogeral.sib.uc.pt/bitstream/10316/43775/1/Upstairs-downstairs.pdf Acesso em: 12 maio 2020.

SANTOS, M. E. B. dos. Da identidade feminina na ficção portuguesa de oitocentos: voz(es) de mulher, perspetiva(s) de autor. 2011. 383 p. Tese (Doutorado em Literatura Portuguesa) — Facultad de Filología, Departamento de Filología Moderna, Universidad de Salamanca, 2011.

SILVA, A. C. Esboço da vida e obra de Maria Amália Vaz de Carvalho. Lisboa: Câmara Municipal, Educação, 1997.

VASCONCELOS, M. C. C. A casa e os seus mestres: a educação no Brasil de Oitocentos. Rio de Janeiro: Gryphus, 2005.

VASCONCELOS, M. C. C. A educação doméstica no Brasil de Oitocentos. Revista Educação em Questão, Natal, v. 28, n. 14, p. 24-41, 2007.

VASCONCELOS, M. C. C. Preceptoras estrangeiras para educar meninas nas casas brasileiras do século XIX. Cadernos de História da Educação, v. 17, n. 2, p. 285-308, ago. 2018. Disponível em: https://doi.org/10.14393/che-v17n2-2018-2 Acesso em: 04 abr. 2020.

VICENTE, A.; VICENTE, F. L. Fora dos cânones: mulheres artistas e escritoras no Portugal de princípios do século XX. Faces de Eva, Lisboa, n. 33, p. 37-51, 2015.

RECEBIDO: $19 / 08 / 2020$

APROVADO: $21 / 09 / 2020$

RECEIVED: 08/19/2020

APPROVED: 09/21/2020

RECIBIDO: $19 / 08 / 2020$

APROBADO: 21/09/2020 